\title{
Anticipating Moral Crisis and Inserting Self-concept of Students
}

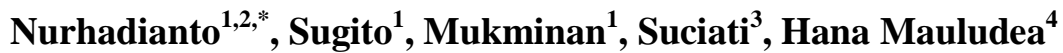 \\ ${ }^{1}$ Graduate School of Yogyakarta State University, Indonesia \\ ${ }^{2}$ Department of Pancasila and Civic Education of IKIP PGRI Pontianak, Indonesia \\ ${ }^{3}$ Faculty of Teacher Training and Education of Universitas Borneo Tarakan, Indonesia \\ ${ }^{4}$ Department of History Education of IKIP PGRI Pontianak, Indonesia
}

Received September 8, 2020; Revised November 19, 2020; Accepted November 29, 2020

\section{Cite This Paper in the following Citation Styles}

(a): [1] Nurhadianto, Sugito, Mukminan, Suciati, Hana Mauludea, "Anticipating Moral Crisis and Inserting Self-concept of Students," Universal Journal of Educational Research, Vol. 8, No. 12A, pp. 7625 - 7630, 2020. DOI: 10.13189/ujer.2020.082548.

(b): Nurhadianto, Sugito, Mukminan, Suciati, Hana Mauludea (2020). Anticipating Moral Crisis and Inserting Self-concept of Students. Universal Journal of Educational Research, 8(12A), 7625 - 7630. DOI: 10.13189/ujer.2020.082548.

Copyright $\odot 2020$ by authors, all rights reserved. Authors agree that this article remains permanently open access under the terms of the Creative Commons Attribution License 4.0 International License

\begin{abstract}
The purpose of this study is to explore information about the efforts made by lecturers to anticipate moral crises and instill student self-concepts. The research approach used is a qualitative case study with research subjects, namely lecturers who teach Civics Education (Civics) courses and students who program these courses at one of the private Universities in West Kalimantan Province, Indonesia. The research process includes observations of the lecture process and interviews conducted by researchers with research subjects about situations, conditions, and subject opinions on the problem's focus. The data analysis technique used is the on-site analysis technique. Verification of the research results' validity was carried out by taking into account the credibility, transparency, and dependability of data collection. The study results concluded that, in general, the efforts made to overcome the moral crisis in students were by providing moral education and giving rewards and punishments to students. Cultivating student self-concept as part of anticipating a moral crisis is carried out by lecturers by listening to student complaints or desires and exploring student self-potential. Therefore, in the learning process, lecturers must pay attention to student morale. Lecturers deliver class lessons, but lecturers must be proactive in paying attention to students' moral condition so that student behavior does not deviate from the rules that apply on campus. Efforts to overcome the moral crisis and instill student self-concept need to be done by lecturers.
\end{abstract}

Keywords Moral Crisis, Self-concept, Case Study

\section{Introduction}

The quality of young human resources desired by a nation is a young generation who are intelligent and have a complete personality in a balanced sense, namely having good, knowledgeable, and skilled self-qualities. Actions that determine the good and bad qualities of a person are determined by moral actions. The moral is a belief about right, wrong, good, and bad by social conventions, which underlie actions or thoughts [1], [2]. The moral is teaching about good and badly received regarding actions, attitudes, obligations, others, morals, and morals.

The rapid pace of information and technology in recent years has impacted various sectors, including digital media. The presence of media such as mobile phones, the internet, and social media, apart from having made major changes, also harms the younger generation, one of which is a moral crisis [3]. Moral values are the basis of social life [4]. Someone who will contribute to the moral crisis occurs when someone acts virtuously and behaves no longer based on the ideal demands used as a reference, namely religious values and cultural values.

A moral crisis is one of the determinants of mental health that can disturb various societal levels [5]. Therefore, 
value education that leads to the formation of morals by the norms of truth is essential for developing human resources in its social context. The target of moral education, according to Masyhur [6] in general, can be directed to:

a). Foster and instill moral values and norms,

b). Improve and expand the value order of a person or group of beliefs,

c). Improve the quality of human beings, groups or life,

d). Counteract, minimize and eliminate negative things,

e). I was fostering and striving for the realization of the expected world.

f). We are clarifying the intrinsic value of moral values and norms and life in general.

Improving moral quality starts with awareness to instill positive values into oneself. When the conscience is filled with negative values that cannot distinguish between right and wrong, someone will cause problems. Cultivation of morals is done through family, community, and college campuses. The moral crisis led to the realization that there was a vacuum in their understanding of themselves [7].

The introduction of self-concepts is an activity that helps students move in a direction that is following their readiness and does not impose external patterns on them. Self-concept is an individual's belief about himself, including the person's attributes and who and what he is [8], [9]. Self-concept is an important part of Self-concept plays an important role in regulating one's behavior and adjustment in life [10].

Moral development always involves the stimulation of development through stages and does not merely teach fixed truths. In general, the introduction of self-concept to moral education concerning rules, attitudes, and behavior.

Overcoming this moral crisis requires lecturers' ability to include an element of education in every teaching effort to gain knowledge and understand ways of life in society, respect for other people's contributions and services, and tolerance of people with different opinions., religion, and customs, interests, and so on.

\section{Materials and Methods}

\subsection{Design}

The efforts that have been made by the lecturer to anticipate a moral crisis in students are traced by using a case study type qualitative approach. This study seeks to reveal and describe how the efforts or steps taken by a lecturer at a private university in West Kalimantan in anticipating a moral crisis in students. The process of collecting information is carried out by uncovering phenomena based on what is known, felt, and carried out by the academic community, namely lecturers and students.

\subsection{Research Subjects}

The determination of research subjects is based on several established criteria. These criteria are 1) setting, 2) actor, 3) event or activity, and 4) process. The first criterion is set, where the data collection process occurs, namely in the learning process on campus, formal and informal interviews, and official and informal communication. This research was conducted at a private university in West Kalimantan Province in Indonesia.

The second criterion is the perpetrator, which is meant by lecturers of civic education courses and students. Lecturers involved are one person with certain criteria determined by the researcher, namely lecturers who have made efforts to overcome the moral crisis and have much information regarding students' moral crisis. The students involved were six students of class A and B Semester II Study Program of Physical Education, Health and Recreation (PENJASKESREK).

The third criterion is the event or activities. The event referred to as a lecture is a synergistic interaction between lecturers and students in tertiary institutions. The lectures that the researchers observed were lectures in the civic education course, one of the general subjects and must be held in Indonesia's universities.

The fourth criterion is the process, which includes observations of the lecture process and interviews conducted by researchers with research subjects about situations, conditions, and subject opinions regarding the problem's focus in this research.

\subsection{Data Source}

Sources The data sources used in this study consisted of:

1. Field data in the form of lecture observation notes

2. Documents in the form of textbooks, teaching materials for lecturers.

3. Respondents consisting of lecturers and students

\subsection{Data Collection Techniques}

research data collection was carried out using observation, documentation study, interviews, and discussions with respondents. The notes and documents used are documents that can be witnesses of the phenomenon being investigated. Researchers also conducted in-depth interviews by asking questions based on the study's focus and purpose and further tracing the respondents' answers. Communication takes place face-to-face. The respondent's movements and expressions can be observed because the interviews conducted to capture the respondent's understanding or ideas and express the subject's feelings and experiences. Researchers carry out the observation technique to observe the respondent's lecture process (lecturer). 


\subsection{Data Analysis}

Data collected was then analyzed using data analysis techniques on the website developed by Miles Huberman [11]. The stages of analysis carried out are, 1) collecting data followed by reading, studying, and reviewing all the data/information obtained, 2) reducing data by making a basic summary by sorting and simplifying the data or information obtained and putting aside unnecessary data, 3 ) compiling the data obtained then proceed with making categorization so that trends can be described which are then presented in the form of tables and descriptive narrative.

\subsection{Verification of the Validity of Research Results}

Verification of the validity of the research results concerning credibility, transferability, and dependability data collection. The research results' credibility results' credibility is carried out by observing the lecture process continuously for a relatively long time (one semester). Data verification is also done by triangulating data, comparing the results of field observations and interviews with lecturers and students. Respondents were also allowed to read research results to provide additional information, strengthen, improve, and conclude according to their perceptions.

Transferability is carried out to determine whether the research results can be implemented in other situations. The author presents in detail the findings and provides recommendations for possibilities that can be done based on the research results.

The last criterion is dependability. Researchers make field notes, video recordings, record observations, and analyze documents. The research steps were carried out systematically, planned, and consistently.

\section{Findings and Discussions}

The educational environment is a vehicle that is conducive to students' growth and mental and moral development. Therefore, the campus is expected to function as a cool area to conduct socialization for children in mental development, social morals, and all aspects of their personality.

\subsection{Citizenship Education Lecturers' Efforts to Anticipate Student Moral Crises}

Based on the research findings, it is found that citizenship education lecturers have carried out several activities to anticipate the moral crisis of PENJASKESREK students. The efforts made by the lecturer include providing education, providing good examples, and providing motivation to students always to anticipate the moral crisis that is hitting teenagers, especially students on campus.

Education is an attempt to change individual behavior [12]. Education consists of three main elements: students, teachers, and programs that continuously interact with each other [13]. The education system's efficiency and productivity depend on these three elements working in harmony to achieve certain goals.

The interviews conducted by researchers with Citizenship Education lecturers (code D1) provide information that the method used to provide education in overcoming student moral crises is by providing good examples and providing motivation to students. Lecturers provide good examples, such as lecturers coming to class on time, lecturers with good behavior, lecturers using polite and polite language when delivering subject matter, and others. Lecturers also provide motivation. Building morals starts with education. It follows the research results [14], which concluded that building the country's character starts with an education that starts at school. Educational outcomes will reflect the quality of a country, which will impact human resources.

Confirmation to respondent D1's answer about the efforts made in anticipating student moral crisis is done by asking students questions. The findings of interviews with students are presented in Table 1.

Table 1. Lecturer Activities in Anticipating Moral Crisis of Student

\begin{tabular}{|c|l|}
\hline Respondents & \multicolumn{1}{|c|}{ Lecturer Activities } \\
\hline M1 & $\begin{array}{l}\text { lecturers provide education in overcoming student } \\
\text { moral crises by providing explanations of moral } \\
\text { crisis material presented in a relaxed manner and } \\
\text { providing examples easy to understand }\end{array}$ \\
\hline M2 & $\begin{array}{l}\text { lecturers provide education in overcoming student } \\
\text { moral crises is that the lecturers give lessons on } \\
\text { moral crises clearly }\end{array}$ \\
\hline M3 & $\begin{array}{l}\text { lecturers provide education in overcoming student } \\
\text { moral crises by explaining how to behave morally }\end{array}$ \\
\hline M4 & $\begin{array}{l}\text { lecturers provide education in overcoming student } \\
\text { moral crises; namely, the lecturers give crisis } \\
\text { lessons Morals are very clear and easy to } \\
\text { understand. }\end{array}$ \\
\hline M5 & $\begin{array}{l}\text { teaching civics lecturer is already very good } \\
\text { because he teaches more about how to behave in } \\
\text { everyday life and he teaches objectively }\end{array}$ \\
\hline M6 & $\begin{array}{l}\text { The lecturer who taught us about the crisis s } \\
\text { morally good, understandable, and clear. }\end{array}$ \\
\hline
\end{tabular}

Researchers also made observations to see lecturers providing education to anticipate moral crimes against students. Education provided by lecturers is carried out in various ways. In general, the way that is done by lecturers is by providing good examples or examples to students so that they are willing to follow the advice given by the lecturer and by motivating students to continue to be aware of the crisis morale is plaguing teenagers now. The example given by the lecturer is one way of bringing the real context that is often experienced by students in the learning process. It helps connect the knowledge gained in class with its application in everyday life [15]. The rules set 
by parents or teachers are one way of shaping and developing children's morality [16],[17]. The concepts presented are connected to students' experiences to feel that what they are learning is related to their daily lives.

Besides providing education about moral crises to students, lecturers also give appreciation or reinforcement to students who have good morals and punish students who violate campus rules. The lecturer explained it during the interview. The answer given by the lecturer was "the lecturer gives praise and strict sanctions to students who violate the established campus rules." The lecturer's answer proved that the lecturer always cares and pays attention to student morale by giving awards or praise and giving strict sanctions. Praise or appreciation is given to students who have good morals. That is, students can behave politely and obey the established campus rules. At the same time, students are given punishment or sanctions if students violate the established campus rules. The sanctions given are not physical but in the form of lessons that deter students and do not repeat their mistakes.

Regarding Civics lecturers' answers about giving rewards and punishments, researchers asked students questions. The results were as presented in Table 2.

Table 2. Lecturer Activities in Providing Rewards and Punishment

\begin{tabular}{|c|l|}
\hline Respondents & \multicolumn{1}{c|}{ Lecturer activities } \\
\hline M1 & $\begin{array}{l}\text { how to deal with children who violate a good } \\
\text { moral crisis by deterring children. For example, } \\
\text { telling the child to do activities to clean the class, }\end{array}$ \\
\hline M2 & $\begin{array}{l}\text { how to fix the moral crisis, one of which is to give } \\
\text { a parent's summons and give a warning letter }\end{array}$ \\
\hline M3 & $\begin{array}{l}\text { usually, the lecturer prefers physical punishment } \\
\text { to the brain, such as running around the field or } \\
\text { cleaning the sports lab and usually only being } \\
\text { warned }\end{array}$ \\
\hline M4 & $\begin{array}{l}\text { One of the ways to fix the moral crisis is using } \\
\text { physical punishment because that way they can } \\
\text { deter }\end{array}$ \\
\hline M5 & $\begin{array}{l}\text { The punishment that can overcome the moral } \\
\text { crisis in adolescents is to provide punishment that } \\
\text { educates and positively impacts their learning } \\
\text { system. For example, when violating Civics } \\
\text { lessons' existing regulations, the child is punished } \\
\text { by memorizing the law. }\end{array}$ \\
\hline
\end{tabular}

Overall, it can be concluded that the efforts made by the lecturer to anticipate the moral crisis have been made well. The efforts made by the lecturers were to provide moral education and give awards and strict sanctions to students who violate campus rules. Moral education is one way to overcome moral decadence that occurs in the younger generation [18]. Moral education needs to be directed towards planned efforts to ensure the morale of children who are expected to become citizens who love their nation and homeland, can create and maintain peace and harmony in society and the nation in the future.

Empowering value education intensively in the family, campus, and community is an effort to anticipate the moral crisis. The family is a guideline for the development of socially acceptable behavior and moral forms [19]. Civics lecturers provide education in overcoming student moral crises in various ways, such as providing good role models for students and providing motivation to behave well and comply with applicable regulations, both in the family, campus, and community environment. It is in line with the thought of Lickona [20], which states that a good character must contain three components: moral knowledge, moral feelings, and moral action. The three components run systematically and sustainably in developing moral education.

The rewards and punishments given by Civics Lecturers to students in overcoming moral crises are based on the factors that make up students are deterred and educate students always to obey the rules. It is done to improve morale, and students can behave well in the family environment, campus, and society.

The lecturer was done for students' good so that the moral crisis could be handled properly and did not harm students' moral development. The effort that lecturers can make as educators is to instill values by internalizing the student's personality [21]. When the values that have been embedded and thrive in the student's personality, in the future, students will become young generations who are smart, skilled, and have high morals

\subsection{The Efforts of Lecturers to Instill Students' Self-concepts}

Through interviews with D1 lecturers, information is obtained that the subject made several attempts to instill student self-concept. Lecturers care and are willing to listen to complaints or problems and students' desire to form better self-concepts. A good self-concept is meant to be a self-concept that brings students to have noble character and competencies that are useful for themselves, their families, communities, nation, and state. Self-concept is related to student achievement [22].

Table 3. Lecturer Activities Embedding Student Self-concept

\begin{tabular}{|c|l|}
\hline Respondents & \multicolumn{1}{|c|}{ Lecturer activities } \\
\hline M1 & $\begin{array}{l}\text { lecturers have ever listened to student complaints } \\
\text { or desires in forming student self-concepts by } \\
\text { providing suggestions }\end{array}$ \\
\hline M2 & $\begin{array}{l}\text { lecturers listen to input from students about } \\
\text { complaints or student desires in forming student } \\
\text { self-concepts }\end{array}$ \\
\hline M3 & $\begin{array}{l}\text { lecturers PPKn have ever listened to student } \\
\text { complaints or desires in shaping student } \\
\text { self-concepts, such as learning a little relaxed but } \\
\text { seriously ly lecturers have ever listened to student }\end{array}$ \\
\hline M4 & $\begin{array}{l}\text { PPKn lects or desires in forming student } \\
\text { complaints or } \\
\text { self-concepts by providing input to students, }\end{array}$ \\
\hline M5 & $\begin{array}{l}\text { PPKn lecturers have ever listened to complaints or } \\
\text { wish students informing student self-concepts by } \\
\text { giving an idea to students how important it is to } \\
\text { maintain a good self-concept }\end{array}$ \\
\hline M6 the & $\begin{array}{l}\text { The lecturer has ever listened to student } \\
\text { complaints or desires in forming student } \\
\text { self-concepts }\end{array}$ \\
\hline
\end{tabular}


Researchers also confirmed the response of the D1 subject by conducting interviews with students who were taking D1 lectures. The results of an in-depth search of student responses are presented in Table 3.

Researchers' observations on When D1 lecturers conduct the lecture process show that the lecturer tries to approach students and determine students' problems. Subject D1 also tries to find a solution to the problem. It is done by the lecturer to foster a good student self-concept and to teach students how important self-concept is because self-concept will determine which direction students will behave or act.

In general, it can be concluded that the lecturer listens to the complaints or desires of students, informing student self-concepts so that the potential that students have in developing self-concepts can be raised. The methods used by the lecturer include providing input and an overview of how important self-concept is in life, both within the family, community, and campus. Women's self-concept will be more optimized if you meet an expert who is also a woman [23].

In addition to only listening to students' self-concepts, the lecturer understood the student's self-concept by exploring the potential that existed in students concerning forming student self-concepts. The results of interviews conducted with the subject D1 concluded that the lecturer explored the potential that exists in students in terms of forming student self-concepts by involving students in every activity on campus. The response given by the lecturer was related to the activity of exploring the potential that exists in students in terms of forming student self-concepts confirmed by conducting in-depth interviews. The findings obtained are presented in Table 4 below.

Table 4. Activities Lecturer Explores Potential Student

\begin{tabular}{|c|l|}
\hline Respondents & \multicolumn{1}{|c|}{ Activities Lecturer } \\
\hline M1 & $\begin{array}{l}\text { lecturer tried to explore the potential that is in } \\
\text { the students by way of involving students in an } \\
\text { activity }\end{array}$ \\
\hline M2 & $\begin{array}{l}\text { lecturers are always trying to engage students in } \\
\text { an activity of SMEs/ ORMAWA in Campus }\end{array}$ \\
\hline M3 & $\begin{array}{l}\text { the potential of the students continue to be } \\
\text { explored by student participation in a } \\
\text { UKM/ORMAWA activity on the campus }\end{array}$ \\
\hline M4 & $\begin{array}{l}\text { lecturer to be able to see the potential of } \\
\text { students by making a UKM/ ORMAWA activity }\end{array}$ \\
\hline M5 & $\begin{array}{l}\text { my lecturer gives an idea to his students how } \\
\text { important it is to maintain self-concept }\end{array}$ \\
\hline M6 & $\begin{array}{l}\text { lecturers always make students have skills as } \\
\text { the results of the teaching and learning process }\end{array}$ \\
\hline
\end{tabular}

From the results of observations made by the researcher, it can be seen that the lecturer, in addition to listening to complaints from students, the lecturer also tries to explore the potential of students by holding an activity that can bring out the student's talents or potentials - students in all areas of life. Examples of activities set up by lecturers are UKM / ORMAWA activities on campus. In addition to developing self-concept dynamically and actively, it can also be built passively through naturally built relationships with the people around them [24].

Overall, it can be explained that civic education lecturers' efforts to instill student self-concepts in the PENJASKESREK Study Program. Based on the results of interviews with lecturers and students and the results of observations of the lecture process, it can be concluded that the lecturer tries to listen and tries to find solutions and explore the potential that exists in students concerning forming student self-concepts.

The lecturer listens to students' complaints or desires, informing student self-concepts so that students' potential in developing self-concepts can be raised. The methods used by the lecturer include providing input and an overview of how important self-concept is in life, both within the family, community, and campus. A positive self-concept is one of the desired outcomes in several social science disciplines [25].

Lecturers always explore the potential students have in shaping student self-concepts by holding extracurricular activities and involving students in these activities. Extracurricular activities are intended to trigger students to explore their potential and compete with other students in finding talents that exist in each of them.

\section{Conclusions}

The research results show that the lecturers have made efforts to overcome the moral crisis and instill self-concept. Efforts made to overcome students' moral crises are providing moral education and giving students rewards and punishments. Citizenship Education Learning must pay attention to student morale, meaning that it does not just deliver class lessons. However, lecturers must be proactive in paying attention to students' moral conditions so that student behavior does not deviate from the rules that apply on campus. Efforts to overcome the moral crisis and instill student self-concept need to be done by lecturers. Cultivating student self-concept as part of anticipating a moral crisis is carried out by lecturers by listening to student complaints or desires and exploring student self-potential.

\section{Acknowledgments}

The author would like to thank the Indonesia Endowment Fund for Education (LPDP) to support his study.

\section{REFERENCES}

[1] Ibung Dian, "Mengembangkan Nilai Moral Pada Anak", PT. 
Gramedia Jakarta, 2009, pp. 3.

[2] Wallace, G \& Walker, A. D.M., "The definition of morality", Taylor \& Francis, 2020, pp. 2

[3] Nursalim M., "Peran Konselor dalam mengantisipasi krisis moral Anak dan remaja Melalui Pemanfaatan Media Baru”, Jurnal Bikotetik Vol. 01. No. 02, pp. 37-72, 2017, DOI: http://dx.doi.org/10.26740/bikotetik.v1n2.

[4] Churchland Patricia S., "Braintrust what Neuroscience tells Us about Morality," Pricenton University Press. USA, 2011, pp. 12 .

[5] Anita Ho \& Joshua S. Norman, "Social Determinants of Mental Health and Physician Aid-in-Dying: The Real Moral Crisis," The American Journal of Bioethics, Vol. 19, No. 10, pp. 52-54, 2019, DOI: 10.1080/15265161.2019.1654025.

[6] Masyhur Kahar, "Membina Moral dan Akhlak" Rineka Cipta, 2000, pp. 27

[7] Weiss, E., "The interrupted sacrifice: Hegemony and moral crisis among Israeli conscientious objectors," American Ethnologist, Vol. 38, No. 3, pp.576-588, 2011, doi:10.1111/j.1548-1425.2011.01324.x.

[8] Baumeister, R. F., "The self in social psychology. Philadelphia”, PA: Psychology Press (Taylor \& Francis), 1999 , pp. 2-3.

[9] Oyserman, D., Elmore, K., \& Smith, G., "Self, self-concept, and identity. In Handbook of Self and identity, $\left(2^{\text {nd }}\right.$ ed $)$, New York: Guilford Press, 2012, pp. 69-104.

[10] Harlock,Elizabeth B., "Perkembangan Anak Jilid 1", Jakarta:Erlangga, 1999,pp. 235.

[11] Miles, M.,B., \& Huberman, A. Michael, "Qualitative Data Analysis" ( $2^{\text {nd }}$ ed), London: Sage Publications, 1994, pp. $19-20$.

[12] Bahri, S., "Implementasi Pendidikan Karakter dalam Mengatasi Krisis Moral di Sekolah”, Jurnal Pendidikan Islam, Vol. 3, No. 1, pp. 57-76, 2015 https://doi.org/10.21274/taalum.2015.3.1.57-76.

[13] Nurdan Baysal Zeliha, Arac Kamil Ersin, "Conditions Determining Quality in HigherEducation: Factors Affecting Satisfaction Levels of Prospective Teachers" Universal Journal of education research, Vol. 7, No. 1, pp. 250-258, 2017, DOI: 10.13189/ujer.2019.0 70132.

[14] Nuryana Z., Nurcahyati I., Rahman A., Setiawan F., \& Fadillah D., "The Challenges and Solutions of Teachers'
Problems to Achieve Education Golden Era," Universal Journal of Educational Research 8(2): 583-590, 2020 DOI: 10.13189/ujer.2020.080230

[15] Suciati, Kartowagiran, B., Munadi, S., \& Sugiman, "The Single-Case Research of Coastal Contextual Learning Media on the Understanding of Numbers Counting Operation Concept," International Journal of Instruction, Vol. 12, No. 3, pp. 681-698, 2019, https://doi.org/10.29333/iji.2019.12341a

[16] Jambon, M., \& Smetana, J.G. Moral Development, theories of. International Encyclopedia of the Social \& Behavioral Sciences, 788-795, 2015.doi:10.1016/b978-0-08-097086-8. 23201-7

[17] Tan W.N., \& Yasin M, "Parents' Roles and Parenting Styles on Shaping Children's Morality" Universal Journal of Educational Research 8(3C): 70-76, 2020 DOI: 10.13189/ujer.2020.081608

[18] Cahyo Edo Dwi, "Pendidikan karakter guna menanggulangi dekadensi moral yang terjadi pada Siswa Sekolah Dasar" Jurnal Pendidikan Dasar, Vol. 9, N0.1, pp. 16-26, 2017, https://ejournal.upi.edu/index.php/eduhumaniora/article/vie w/6150/4157.

[19] Mehmet Acet, Tamer Karademir, Sercan Gökçiçek, "Analysis of the Influence of Adolescence Period SportActivities on Emphatic Tendency," Universal Journal of Education Research, Vol. 5, No. 2, pp. 186-193, 2017, DOI: 10.13189/ujer.2017. 05020.

[20] Lickona, Thomas, "Mendidik Untuk Membentuk Karakter", Jakarta: Remaja Rosdakarya, 2013, pp. 85.

[21] V. Zeigler-Hill, T. K. Shackelford, "Encyclopedia of Personality and Individual Differences," https://doi.org/10.1 007/978-3-319-28099-8_2001-1

[22] Hattie John, "Self-concept. Psychology", Press. New York, 2014, pp. 36-38.

[23] Stout, J. G., Dasgupta, N., Hunsinger, M., \& McManus, M. A., "STEMing the tide: Using ingroup experts to inoculate women's self-concept in science, technology, engineering, and mathematics (STEM)," Journal of Personality and Social Psychology, Vol. 100, No. 2, pp. 255-270, 2011, https://doi.org/10.1037/a0021385.

[24] Elliott, A., "Concepts of the self," PolicyPress, 2001.

[25] Marsh Herbert W., "Academic Self-Concept: Theory, Measurement, and Research," In Psychological perspectives on The Self. Psychology Press. New York, 2014, pp. 60. 